INTERNATIONAL JOURNAL OF

\title{
The Strategy of Educational Programs for Confrontation the Crisis of COVID 19
}

\author{
DR. Aya Mohamed Kamal EIDean Amean \\ Lecturer -Faculty of fine arts - Alexandria University \\ ayaMohamed.Kamal@alexu.edu.eg
}

\author{
DR. Ayat Abdalla Fawaz Soltan \\ Lecturer -Faculty of fine arts - Alexandria University \\ ayat.fawaz@alexu.edu.eg
}

\begin{abstract}
:
Since the end of 2019 and the beginning of 2020, the world woke up to a catastrophe That couldn't be controlled until now, the spread of a dangerous lung virus, COVID19, which is one of the most dangerous viruses known at present time.

Its danger lies in its threat to human life and the inability to control its spread, in addition to the human and economic losses it has caused. I am not talking here about this disease as the first that brought us such unfortunate events, it was preceded by many disasters that darkened the whole world over the past time. But I am surprised that the world did not take specific actions in the past to control this type of disaster, but in the current time, we have found that the whole world has united and gathered to confront this rapidly spreading disease because the world has realized the importance of collective dealing with this kind of Crises, so all countries raced either to try to control to find a solution for the spread of this disease, and they rushed to push all their scientists, sciences, economic and human capabilities at the global level to try to put an end or confront this monster, the world now realized that science is the only way To confront this kind of crisis.

So the world defied this spread and insisted on continuing the educational process with various means to survive. Computer and communications companies raced to establish educational platforms, and educational institutions, in turn, decided to use the platforms to maintain the continuity of the educational process and the ease of communication through them and the exchange of information and research through them.
\end{abstract}

\section{Introduction:}

The Arab Republic of Egypt and the Ministry of Higher Education have followed many Procedures to maintain the continuity of the educational process, to implement what was approved by the state, the University of Alexandria, in turn, followed specific strategies that were discussed at the level of the university's faculties, and the College of Fine Arts applied these strategies to deal with the nature of the study in college. 
INTERNATIONAL JOURNAL OF

This study discusses the most important strategies followed in the Department of Decoration, Faculty of Fine Arts, Alexandria University, as a model for following the hybrid education system and the most important ways taken to reach that system to the desired educational goals through activating the educational platform system in practical and theoretical lectures and final exams for different teams, and methods Evaluation and follow-up to the announcement of the results to maintain the continuity and quality of the educational process.

\section{Research problem:}

Were the countries of the world be able to maintain the continuity of the educational process by applying modern teaching methods and using interactive platforms, and how did the University of Alexandria and the College of Fine Arts, in turn, take Procedures to complete the educational process with it, to save lives and prevent the spread of disease.

\section{Research Objective:}

Knowing the procedures taken by the world to confront the rapid spread of the disease and its impact on the educational process, and the procedures are taken to save the educational process and examination systems in Egyptian universities in general, and the measures taken by the Faculty of Fine Arts, Alexandria University in particular.

\section{Research methodology}

Monitoring and analyzing all the Procedures that was taken to save the educational process.

\section{$\underline{\text { Research procedures: }}$}

\section{The beginning:}

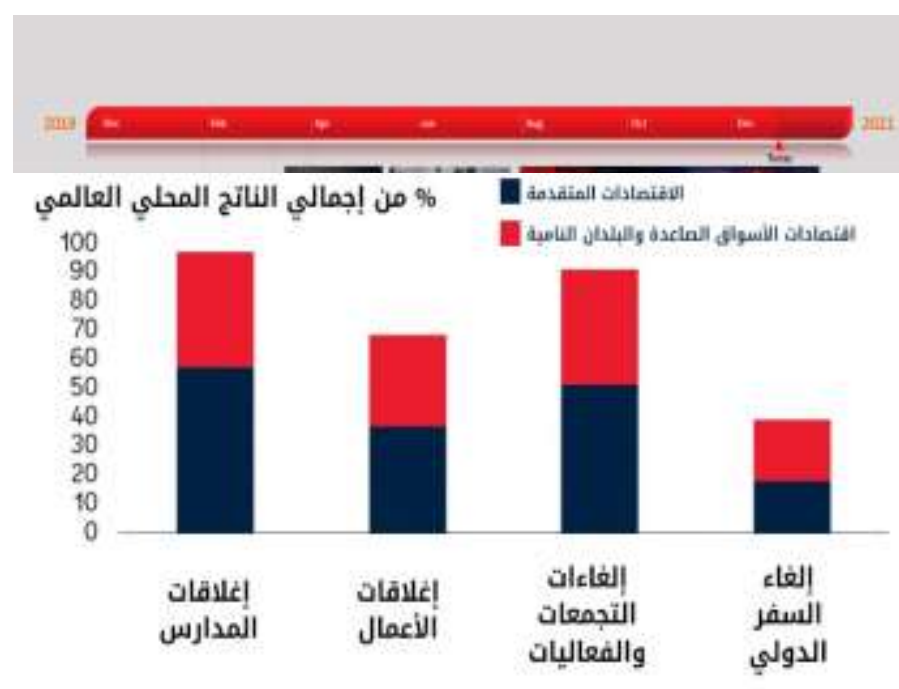

On December 1, 2019, the world woke up on the first appearance of symptoms of unknown pneumonia, followed by that on December 31, 2019, another appearance of the same symptoms on another patient, no clear links were found between the two patients and the group of patients who later had the same symptoms in the Wuhan seafood market, then reports were sent from the health authorities in China to the World Health Organization 2019 reported that there was a cluster of infections with the same pneumonia virus in the city of Wuhan, the World Health Organization officially declared the outbreak of the epidemic. 


\section{INTERNATIONAL JOURNAL OF EDUCATION AND LEARNING RESEARCH}

VOLUME 3, ISSUE 2, 2020, $44-51$.

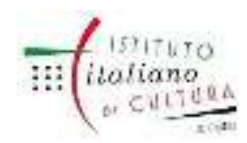

www.egyptfuture.org/ojs/

This epidemic affected the world with all its educational, economic, and social systems, and led to the closure of schools, educational institutions, and areas that contain gatherings all over the world, as a quick response to what was recommended by UNESCO and the World Health Organization to limit the rapid spread of the disease, and education systems shifted to distance education.

The outbreak of the epidemic led to a state of global emergency with confirmation of an increase in infection and death rates in various countries of the world, and all of these events had serious economic and social consequences, Educational applications and platforms have been opened To provide communication between teachers and students of all educational levels to reduce educational interruption.

\section{Actions that have been taken:}

The Egyptian government has taken specific strategies and the Egyptian universities have taken many gradual Procedures depending on the extent of the virus spread. Accordingly, the University of Alexandria has also taken several strategies represented in Appling the Recommendations of the Ministry of Higher Education to facilitate the educational process at the level of Egyptian universities to confront the disaster.

\section{As for the level of the Faculty of Fine Arts, Alexandria University:}

On March 16, 2020, the faculty established electronic platforms to follow up on students' work and to provide a daily report on developments in uploading lectures to the platforms. then on March 22, 2020, an announcement was issued by the College's Crisis Committee, based on the decisions of the Supreme Council of Universities, and Postponing any (exams) during the suspension period and only correcting students' work and giving them a formative degree, Canceling the mid-semester exam and adhering to the requirements during the lecture time so that the subjects do not conflict with each other.

\section{March 24, 2020}

The Prime Minister decided urgently to confront Corona, and it was decided to follow up and correct what the students have done and reduce and simplify what is required without setting any grades because the purpose is to continue the educational process without burdening students with what they don't have any power to do, and those evaluations will be postponed until they return from this crisis, with emphasis on Lifting the absence from this period and confirming that the lecture will be held on time. 


\section{INTERNATIONAL JOURNAL OF EDUCATION AND LEARNING RESEARCH}

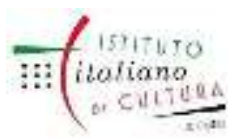

\section{Since March 25, 2020}

The decoration department board sessions have been transformed into an online meeting system, the role of team coordinators began by creating a WhatsApp group to determine the required and specific tasks from the scientific department. The tasks were as follows:

Follow-up on the establishment of educational platforms Google classroom to complete the courses in the semester and follow up the regularity of students' entry on these platforms.

- Reporting the attendance and absence of

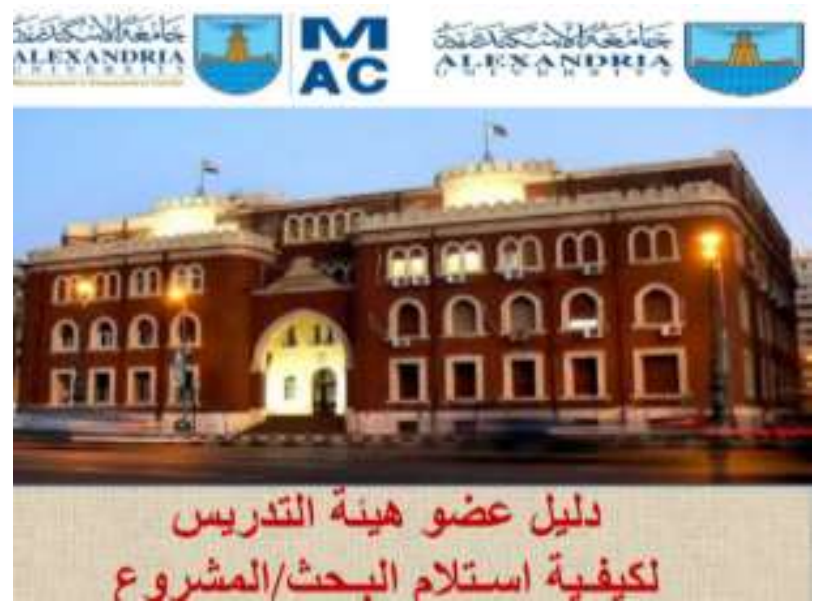
students on these platforms and communicating with students to provide support and solve problems related to the educational process during the crisis.

- Organizing the receipt of evaluation criteria for academic teams.

- Receiving the research projects from the head of the department and the faculty members to prepare for their submission to the podium.

- Follow up on the establishment of the unified platform to raise new research projects, Microsoft Teems, and ensure that all students in the different academic teams are included on the new platforms in preparation for raising research projects.

- Raising the evaluation criteria and research projects on the platforms for the different courses of each team separately during the examination process

- Follow up the attendance and absence of students during the period of uploading research projects on the specified platforms.

- Submitting periodic reports to students who have submitted their projects.

- Identifying the problems that occurred while uploading the students' research projects, which may be technical problems or problems related to the student's inability to upload, and trying to find solutions to these problems.

- After the department's control makes an e-mail to receive the students' problems and try to solve them, the team coordinators receive these complaints and try to communicate with the students to solve them.

- Compiling research projects and attendance and absence reports for academic teams and handing them over to the department and control.

\section{Since April 2020:}


INTERNATIONAL JOURNAL OF EDUCATION AND LEARNING RESEARCH

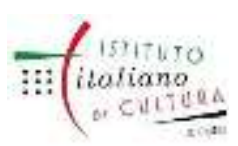

An indicative summary and a set of Arabic and English technical points were presented for the open book test from home, and all faculty members were invited to attend the meeting of the decoration department, which extended from its day at 8 p.m. on the application of zoom ... to prepare the appropriate method for implementing the decisions of the Supreme Council of Universities for the examinations, And present their perceptions of how to implement the alternatives proposed by the Supreme Council of Universities regarding the exams in their decisions to be discussed and approved by the Council.....1- Article

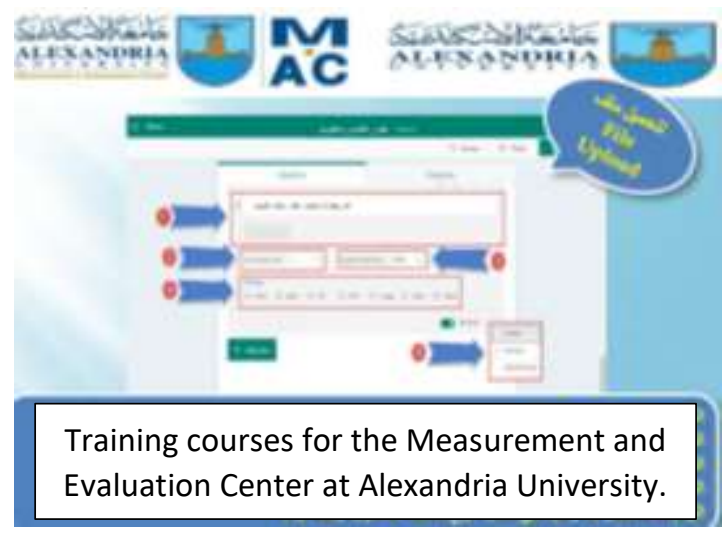
research-2- Research project-3- portfolio-A4- Daily take-home exam.

The minimum limit for passing theoretical and, practical courses have been determined, the plagiarism percentage has been determined and approved by the Scientific Department Council, and these mechanisms have been announced to students, The Supreme Council of Universities also decided to treat the remaining students for re-examination, or those who took the exam from abroad, or students who did not pass courses from previous years, as the treatment of new students in terms of allowing them to prepare acceptable research (a research article - a research project - reference research) or to pass electronic exams in the courses Which were studied in this semester as decided by the University Council to choose one of the two alternatives mentioned above and by the mechanisms and controls previously established in this matter.

The Council also emphasized the continuation of the implementation of all the decisions previously taken in its 699th session, regarding which the Minister of Higher Education and Scientific Research Resolution No. 1290 of 2020 was issued, and that the Council was interested in students completing the semester to achieve the minimum requirements for study.

\section{In May 2020}

A zoom meeting was held to explain the Microsoft team to the faculty members to help students submitting research projects, and the team coordinators were assigned from faculty members to create electronic platforms to present research projects for the different stages, and the examiner's committees and exam schedule were announced, announced of the university e-mail for students and faculty members has been activated to complete the examination process on the announced platforms and approved by the University of Alexandria

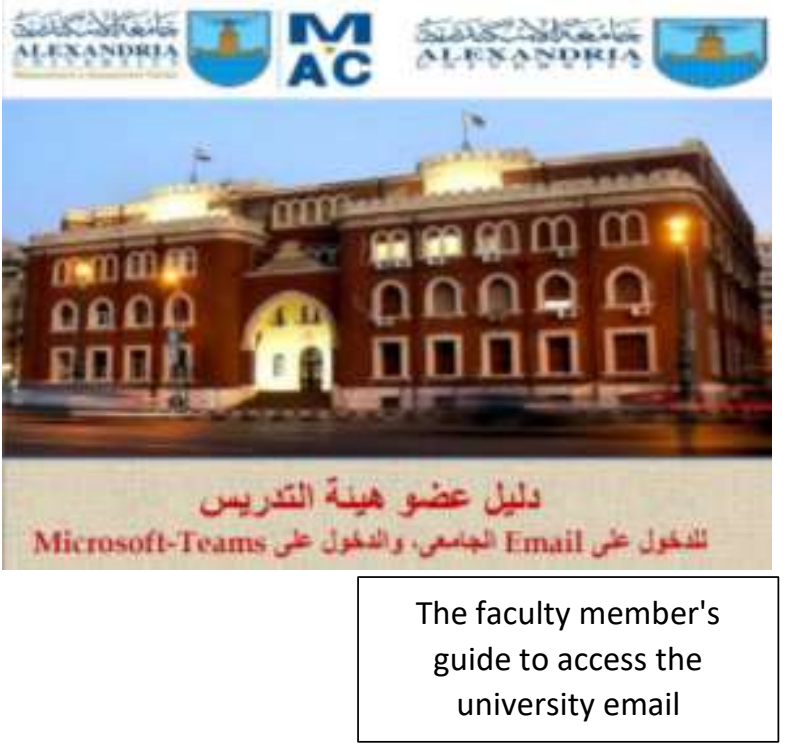


INTERNATIONAL JOURNAL OF

EDUCATION AND LEARNING RESEARCH

Microsoft teams, and a mechanism has been activated to deal with student complaints while submitting research projects.

\section{At the end of May 2020}

The statements of the examination committees were handed over to monitor the grades of the research projects for the correction committees so that the first stage would be completed and the second stage would begin.

The mechanism for implementing the decisions of His Excellency the Minister issued to us by the Supreme Council of Universities:

First, about the theoretical courses:

1. A question is drawn up for the subject of the article research - the reference research from a committee of examiners of five professors headed by the professor of the subject and the person in charge of teaching.

2. The research topic is what the student studies during the semester.

3. The professor announces the research methodology, specifications, and evaluation criteria before starting it so that the research does not exceed 15 papers and consists of 1000 words as a minimum, and is supported by pictures and comments. It is preferable to commit writing in fonts 12 for the body and 14 for the titles Times New Roman.

4. It is difficult to detect citation rates due to a large number of students.

5. If the student reaches $50 \%$ of the criteria specified for the assessment, the student is considered successful, and if he does not reach the minimum level, he is considered a failure, and the student can present his research again.

6. If the student fails again, the rules and regulations governing the students who fail will apply to him.

\section{Second: Regarding the courses that are evaluated orally according to the regulations:}

1. Research projects outlined and formulated by the professor of the subject are put forward with the approval of the committee composed of all the professors in charge of teaching.

2. The topic of the research project is a continuation of student projects that are being followed up throughout the semester before and during the suspension.

3. The student delivers the research stages of the project and works in a systematic way and style, through which he explains the development of the idea - the objectives - the body of the project, and the analytical theoretical framework to reach the desired results according to the ILOs for each subject.

4. The student announces the specifications for submitting the research project so that it does not exceed 15 pages that collect all the paintings and the theoretical framework of the project. The paintings are collected according to what is required in each research project in the form of a 
INTERNATIONAL JOURNAL OF

EDUCATION AND LEARNING RESEARCH

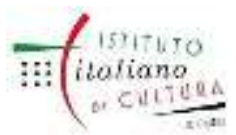

ISSN: $2785-9568$

VOLUME 3, ISSUE 2, 2020, $44-51$.

www.egyptfuture.org/ojs/

single pdf compiled in the name of the student and his number via email or the google classroom platform According to the research delivery schedules attached to the study teams.

5. Students are evaluated through tripartite examination committees according to the preparation of students and rubrics prepared by the question-making committee and delivered to the department and students in advance.

6. A specific date is announced for evaluating each subject on the Zoom application, to discuss with some students if some of the separation points in the projects are not clear, on which the student's success may depend or not.

7. Each professor delivers a copy of the result to the control, where the student's success or failure is calculated according to the average result of the triple examination committee.

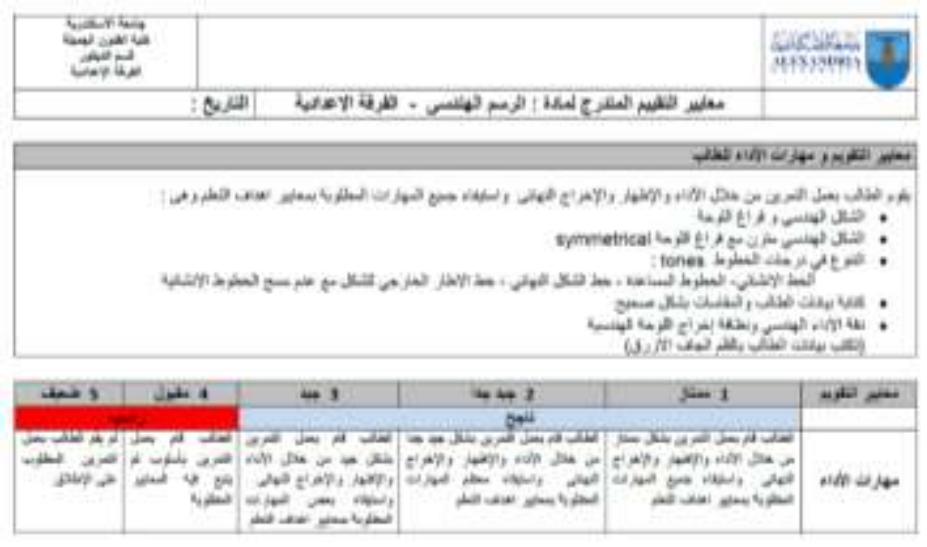

Third: Courses for which exams will be held

1. In these subjects, the student will take open-book exams, which will be announced to the student within the announced examination schedule, and the submission will take place the next day, or as decided by the subject professor.

2. The exam is evaluated by tripartite committees according to the number of students and based on the evaluation criteria announced to the student.

Fourth: Fourth-year Bachelor's degree:

Follow-up continues until May 21, 2020, on remote communication platforms, and exams are postponed until the return of study according to the decisions of the Minister and the Supreme Council of Universities.

Fifth: Announcing the results for the first attempt and receiving objections from students.

Sixth, announcing the students' second attempt and announcing its results.

\section{Conclusion:}

In the context of the global changes that the world has experienced in recent years, and the continuous challenges that the educational system faces to official educational facilities, strategies must be taken to develop educational policies so that the educational system can reach 
INTERNATIONAL JOURNAL OF

the desired goals for the various programs and courses that students study, and so that the graduate has the tools necessary to enter the labor market and the competition and the advantages that the educational program seeks to achieve from the first moment to enroll students to study, Therefore, the existence of the (hybrid education) system and the assessment methods based on that system - is no longer a luxury or a choice that can be abandoned at one time, but rather it has become an urgent necessity to face challenges to reach the desired educational effectiveness.

\section{$\underline{\text { Recommendations: }}$}

Digital transformation and the use of hybrid education has become a major partner in the teaching and learning strategy. It is an important and inevitable matter, whether people suffer from a pandemic or not, to achieve global requirements and determine the absorptive capacities of educational spaces with the need to maintain the quality of the targeted educational outcomes and the quality of the educational process under the supervision of Course professors.

\section{References:}

1. WHO (World Health Organization) reports.

2. Training courses for the Measurement and Evaluation Center at Alexandria University.

3. The faculty member's guide to creating platforms.

4. The faculty member's guide to receiving research projects.

5. The faculty member's guide to access the university email.

Received: October 2020

Accepted: December 2020 